\title{
An Analysis of The Use of ICT Tools and Its Problems in Teaching and Learning Process at SMA Negeri 2 Semarapura
}

\author{
Swandewi, N.K ${ }^{1}$ \\ ${ }^{1}$ Universitas Pendidikan Ganesha, Singaraja, Indonesia
}

\section{A R T I C LE IN F O}

Article history:

Available online on

February, 20 2018

\section{Keywords:}

ICT,

Problems in using ICT,

Tools in teaching and

learning

\begin{abstract}
A B S T R A C T
This study aimed at investigating (1) types of ICT tools implemented in teaching and learning process (2) English teacher' planning of the use of ICT tools in lesson planning (3) procedures implemented in teaching English using the ICT tools (4) the problems faced by English teachers who used ICT tools in teaching and learning process at SMA Negeri 2 Semarapura when using ICT tools in teaching and learning process. This study was descriptive qualitative research involving three English teachers of SMA Negeri 2 Semarapura. The instruments used for data collection were researcher, questionnaire, interview guide, teachers' lesson plan, observation sheet, and recorder. The methods of data collection were survey, interview, lesson plan analysis, observation, and recording. The result of the study showed that English teachers of SMA Negeri 2 Semarapura had already implemented ICT tools in teaching and learning process. Types of ICT tools used were laptop, LCD projector, speaker, video, Power Point, internet, and e-learning namely Quipper School. Before implementing those types of ICT tools, teachers planned ICT tools in the lesson planning. The use of ICT tools were planned explicitely in teaching media and tools as well as learning resources, while implicitely in steps of teaching and learning activity. In implementing ICT tools, the teachers had their own procedures which depended on types of ICT tools used and topic taught. Teachers encountered four main problems namely infrastructural problems, technical problems, problem of time, and lack of teachers' competence in using ICT tools.
\end{abstract}




\section{Introduction}

Nowadays, technology has become public needs in everyday live. Most of aspects of life cannot be separated from the use of technology. Moreover, in the field of education, it has become a necessary. ICT (Information and Communication Technology) is considered as tools in education since learning is dealing with information which can be gathered through the use of technology. Mikre (2011:71) states that ICT is tools for examining information which enable students to construct new information.

In 21st century learning, the combination of skills in using technology has been used in teaching and learning process. It is considered that ICT has a significant impact on the success of learning process. Thus, in 21st century, having ability in integrating the use of ICT in the teaching and learning process has become a must for the teacher.

ICT has much benefit on education field. It can improve the learners' competencies as well as the learning outcomes. The use of ICT is effective and efficient in the terms of time and place for the learning process. The benefit of using ICT in education is it enables the students to access knowledge resources from any location (UNESCO, 2002, as cited in Lee, 2002). Learning through ICT can make teaching and learning process easier to be conducted whether it is in the school or outside the school. It provides unlimited lessons and references which can be accessed anytime and anywhere. Therefore, teacher is expected to be able to use and integrate ICT in the teaching and learning process.

The teachers and students can implement ICT based learning to make teaching and learning process becomes easier. It can be used to help the teacher and students to find the solution for the problem that they find during the teaching and learning process. In teaching and learning process, the teachers commonly use ICT tools such as laptop, projector, Microsoft Office (Power Point, Word, and Excel), etc. Some teachers also use e-learning in their teaching like using learning platform such as Edmodo, Moodle, etc. To support the use of ICT in teaching and learning process, most schools have provided computer laboratory so that students can make use of it. Moreover, nowadays many students already have their own laptop so that they can bring it to the school for the need of learning process.

The positive effects can be gain through the integration of ICT in teaching and learning process. It can make the learning and teaching process becomes interesting so that it will attract students' attention and increase their motivation in learning. Through combining their knowledge and skill in using ICT, the teacher can make an innovative teaching startegies. Innovative learning process can be gain through the use of ICT, but it depends on the teacher's ability in making it appropriate with the context (Somekh, 1997: 114, as cited in Lee, 2002). In this case, in integrating ICT into teaching and learning process, the teacher should adjust it with the context of the learning. The teacher can take some material from other sources like internet so that the teacher can get many references to teach certain subject in the school. The students can also explore the material given by the teacher by using internet. In this case, they can improve their creativity and develop their critical thinking in solving the problem in their learning. Thus, through integrating ICT into teaching and learning process, the students will be creative, innovative, and it will improve their critical thinking.

ICT is also used in language teaching and learning. In language learning, students communicate with their teacher and also their friends in order to get a new knowledge or some information (Juliari, et al., 2014). It means that learning language is dealing with communication and information in which the ICT can be used as tools in language learning. In language learning, technology makes it possible for the teacher and students to connect and communicate with people all around the world so that they can learn many aspects of language. Thus, teacher should be able to use of ICT in language learning..

Teachers' skill in using ICT is important thing to be considered for the success of learning. Not only mastering certain subject that is taught, but they also have to combine it with their skills in using ICT. The teachers should be able to use technology devices and integrate it into their teaching. Somehow, in reality not all of the teachers are able to do that. In some cases, there are some barriers in the integration of ICT into the teaching and learning process. Thus, teaching and learning process is not going to be optimal when it is used by the teacher in the classroom. Therefore, this research is urgent to be conducted.

Based on the preliminary observation done by the researcher, SMA Negeri 2 Semarapura is one of the schools in Klungkung regency that use ICT in the teaching and learning process. This school is one of the favorite schools in Klungkung regency. Thus, this study was conducted in this school so that it can inspire the other teachers to use ICT in teaching and learning process. This study focused on the use of ICT tools and its problems in teaching and learning process at SMA Negeri 2 Semarapura in academic year 2017/2018. The general purpose of this study was to describe how English teachers used ICT in the teaching and learning process as well as problem faced when the teachers used ICT in the teaching and learning process. 


\section{Methods}

This research was conducted at SMA Negeri 2 Semarapura, which is located on Dewi Sartika Street, Klungkung. The researcher colected the data from August 14th until September 14th 2017. This reserach was descriptive qualitative research. In this study, the subjects were three English teachers of SMA Negeri 2 Semarapura. The object of this research was the use of ICT tools and its problems in teaching and learning process at SMA Negeri 2 Semarapura.

The instruments used for data collection were researcher, questionnaire, interview guide, teachers' lesson plan, observation sheet, and recorder. Meanwhile, the methods used in this study were survey, interview, lesson plan analysis, observation, and recording. The procedures of data collection were asking for permission, doing preliminery observation, choosing the subjects of study, spreading the questionnaire, doing interview, analyzing teacher's lesson plan, conducting observation in the classroom, and analyzing the data.

Interactive Data Analysis Model was used in this study. There were four steps of activities that were systematically used. Those were data collection, data reduction, data display, and conclusion drawing or verification (Miles \&Huberman, 1994 as cited in Setiyawan, 2014).

In order to make the data trustworthy, the researcher used triangulation method. Triangulation is a method which uses something out of the data as comparison to the data (Moleong, 2002: 178, as cited in Dian, 2011). Data triangulation was used by collecting different data, namely the data from questionnaire, interview, lesson plan analysis, and observation. Method triangulation was used by conducting various methods in collecting the data. The methods used were survey, interview, lesson plan analysis, and observation. Thus, the study can recheck its credibility from different point of view.

\section{Findings and Discussion}

This study was conducted in order to describe the use of ICT tools in teaching and learning English as well as English teachers' problem in using ICT tools in teaching and learning process. The research was conducted to English teachers of SMA Negeri 2 Semarapura. Survey, interview, lesson planning analysis, and observation were applied in this study. All of data collected were analyzed quatitatively.

\subsection{The Types of ICT Tools Used by the Teacher}

The result of questionnaire, interview, lesson plan analysis, and observation shows that there were several types of ICT tools used by the English teachers of SMA Negeri 2 Semarapura namely laptop, LCD projector, speaker, internet, video, Power Point, and e-learning that was Quipper School. In this case, basd on the interview, the type of ICT tools that was used the most by the teachers was Power Point which was supported by other tools such as laptop and LCD projector. All of teachers used laptop, LCD projector, speaker, internet, video, Power Point in teaching and learning process. Meanwhile, for e-learning, only teacher 1 who used e-learning that was Quipper School. ICT tools means technical devices such as interactive boards, tablets, computers, etc., and educational software, educational websites, e-learning portals, electronic educational materials, e-books, etc. that should be able to use by teachers in their teaching in which they should perform a role of students' mentors (Jonassen, et al., 2003 as cited in Klement, et al., 2017).

\subsection{The Teachers' Planning of the Use of ICT Tools in the Lesson Planning}

The result of questionnaire, interview, and lesson plan analysis shows that in planning the use of ICT tools, the teachers only plan it administratively in the lesson planning. Lesson planning is the planning of teaching and learning activity for one meeting or more (Peraturan Menteri Pendidikan Dan Kebudayaan Republik Indonesia No 22 Tahun 2016). Lesson planning is developed based on syllabus to direct students learning in order to reach the basic competency. The teachers stated the use of ICT tools explicitly and implicitly in the lesson planning. Explicitly could be seen from the teaching media, tools, and sources. Meanwhile, implicitly could be seen from the steps of teaching and learning activity. The results show that all teachers planned the use of ICT tools in the lesson planning. In implementing ICT tools in teaching and 
learning process, the teachers needed to plan it first in the lesson planning before implementing it in the classroom. The teachers planned it by stating the use of ICT tools in the lesson planning.

\subsection{The Teachers' Procedures in Using ICT Tools in Teaching and Learning Process}

The result of questionnaire, interview, and observation shows that the teachers had their own procedures in implementing ICT tools in teaching and learning process. It depended on types of ICT tools used and the topic taught. For instance, in using e-learning namely Quipper School, the teacher would ask the students to log in on Quipper and search what was instructed by the teacher. The teacher used video and Power Point by using laptop, LCD projector, and speaker to display the video and Power Point. The researcher could synthesize that in general there were six steps of teaching using video or Power Point as stated on the table. Those were procedures which could be implemented by the teachers when they used video or Power Point for teaching.

\subsection{The Teachers' Problems in Using ICT Tools in Teaching and Learning Process}

The result of questionnaire, interview, and observation shows that English teachers of SMA Negeri 2 Semarapura encountered problems in using ICT tools in teaching and learning process. According to Bingimlas (2009), the integration of ICT into teaching and learning process is a complex process in which many difficulties is encountered. It means that the teachers should deal with several problems when they used ICT tools in their teaching. In this case, the researcher found that English teachers of SMA Negeri 2 Semarapura found four main probems in using ICT tools in teaching and learning process. Those problems were infrastructural problem, technical problem, problem of time, lack of skills in using ICT tools, etc.

\subsection{Infrastructural Problems}

Infrastructural problem is the problems of the infrastructure faced such as the lack of infrastructure and the poor condition of the infrastructure itself. It was the main problem encountered the most by English teachers of SMA Negeri 2 Semarapura. The limited number of LCD projector and lack of maintenance of LCD projector in the classroom were the infrastructural problem faced.

The result of observation also showed that the teachers encountered infrastructural problems in using ICT tools in teaching and learning process. The main barriers in integrating ICT into teaching practices perceived by the teacher were lack of pedagogical models, lack of material and content of teaching, and lack of infrastructure such as computers, laptops, and notebooks (Liu, et al., 2015). In this case, this study and the previous study conducted by Liu, et al shows that the teacher encountered infrastructural problems, but the difference is this study shows the infrastructural problem faced was limited number of LCD projector and lack of maintenance of LCD projector in the classroom.

\subsection{Technical Problems}

Technical problem is the problem faced when using or doing something in which the problem is related to the use of electronic devices and technology. The electricity supply, limited access of free Wi-Fi, and VGA cable which did not match with the teachers' laptop were the technical problem faced by the English teachers of SMA Negeri 2 Semarapura.

The result of observation also showed that the teachers encountered technical problems in using ICT tools in teaching and learning process. The most critical barriers to the use of ICT were lack of technical support, lack of hardware, lack of in-serving training, and lack of appropriate software materials (Goktas, et al., 2013). In this study, lack of technical support that was lack of access to free Wi-Fi was the technical problem faced.

\subsection{Problems of Time}

Problems of time in using ICT tools means the problem faced related to the time consuming and the time when the ICT tools were used in teaching and learning process. in this study, if was found that English teachers of SMA Negeri 2 Semarapura encountered the problems of time in using ICT tools in teaching and learning process. It took quite long time to make a new and good Power Point and search a video. Besides, the time needed in preparing the LCD projector and displaying the Power Point particularly in starting or setting the tools was also problem of time encountered by the teachers. 
Additionally, teaching using the Power Point in the afternoon made it hard for the students to see the Power Point because the classroom was too bright because of the reflection of the sunshine.

\subsection{Other Problems}

The other problems here are the the problems faced by the teachers beside infrastructural problems, technical problems, problems of time, and lack of competence in using ICT tools. Based on the data collected, another problem encountered by the teacher in using ICT tools in teaching and learning process was when the teacher used e-learning that was Quipper School, the students frequently forgot their password.

\section{Conclusion}

From the result of this study about the use of ICT tools and its problems in teaching and learning process, it was concluded that the English teachers of SMA Negeri 2 Semarapura already used several types of ICT tools in teaching and learning process such as laptop, LCD projector, speaker, video, Power Point, internet, and e-learning that was Quipper school.

Dealing with the teachers' planning of the use of ICT tools such as laptop, LCD projector, speaker, video, power point, and internet in the lesson planning, it can be concluded that English teachers of SMA Negeri 2 Semarapura already planned the use of ICT tools in the lesson planning. The teachers stated it explicitly in the teaching media and implicitly in the steps of teaching and learning activity in which it depended on the material which was taught.

The English teachers of SMA Negeri 2 Semarapura had their own procedures in implementing ICT tools in teaching and learning process. It depended on the types of ICT tools implemented and the material which was taught. In general, in using video in teaching, the teacher played the video and the students watch it. After that, the teacher conducted the follow up activity which was relevant to the video and gave students chance to ask about the video. Meanwhile, in using the Power Point, the teacher showed the Power Point and asked the students to take a note. Then, the teacher explained material on the Power Point and give chance to the students to ask question about the material.

The English teachers of SMA Negeri 2 Semarapura encountered problems when using ICT tools in teaching and learning process. The problems were infrastructural problems, technical problems, problems of time, and lack of competence in using ICT tools.

In relation to the conclusion above, the suggestion proposed were: (1) it is suggested for the dinas pendidikan and the relevant stakeholders engaged in educational field to insert the ICT skills program to their policy and curriculum. (2) it is suggested for the school to maintain the ICT infrastructure support in order to make reliable ICT tools. The continuity support from the school about the implementation of the ICT tools in teaching and learning process is also suggested in order to motivate the English teachers to keep using ICT tools to create creative and interested teaching. Thus, the quality of teaching and learning can be improved. (3) it is suggested for the teachers to use other types of ICT tools in teaching so that the students are more interested in learning. (4) it is suggested for the other researchers who are interested in this study are suggested to expand this study in the terms of the students' response toward the implementation of ICT tools used by English teachers in teaching and learning process.

\section{References}

Bingimlas, K. A. (2009). "Barriers to the successful integration of ICT in teaching and learning environments: A review of the literature". Eurasia Journal of Mathematics, Science \& Technology Education, 5(3), 235-245. Taken from http://ejmste.com/v5n3/EURASIA_v5n3.pdf\#page=53 (retrieved on June 5, 2016)

Dian, F. (2011). "Problems in Learning English Vocabulary of the Fifth Year Students at MI Miftahul Huda Banjarejo Rejotangan Tulungagung in the Academic Year 2010/2011". Taken from http://repo.iain-tulungagung.ac.id/1236/ (retrieved on June 6, 2016)

Goktas, Y., Gedik, N., \&Baydas, O. (2013). "Enablers and barriers to the use of ICT in primary schools in Turkey: A comparative study of 2005-2011". Computers \& Education, 68, 211-222. Taken from http://www.sciencedirect.com/science/article/pii/S0360131513001231 (retrieved on June 5, 2016) 
Juliari, I. G. A. I. T., Padmadewi, N. N., \& Nitiasih, P. K. (2014). "The Profile of Communication Strategies Used by Junior High School English Teachers in Teach qasxcv ing and Learning Process in SMP Negeri 2 Sukawati". Jurnal Pendidikan Bahasa Inggris, 2(1). Taken from http://119.252.161.254/e-journal/index.php/jpbi/article/view/1383/1062 (retrieved on Mei 28, 2017)

Lee, K. T. (2002). "Effective teaching in the information era: Fostering an ICT-based integrated learning environment in schools". Asia-Pacific Journal for Teacher Education and Development, 5(1), 2145. Taken from http://eprints.qut.edu.au/3909/1/3909.pdf. (retrieved on June 8, 2016)

Lin, C. Y., Huang, C. K., \& Chen, C. H. (2014). "Barriers to the adoption of ICT in teaching Chinese as a foreign language in US universities". ReCALL,26(01), 100-116. Taken from http://journals.cambridge.org/abstract_S0958344013000268 (retrieved on June 8, 2016)

Liu, X., \&Pange, J. (2015). “Early childhood teachers' perceived barriers to ICT integration in teaching: a survey study in Mainland China". Journal of Computers in Education, 2(1), 61-75. Taken from http://link.springer.com/article/10.1007/s40692-014-0025-7 (retrieved on June 5, 2016)

Mcdougald, J. S. (2009). The use of information and communication technology (ICT) in the EFL classroom as a tool to promote L2 (English) among non-native pre-service English teachers (Doctoral dissertation, University of Jaén). Taken from http://asian-efl-journal.com/wpcontent/uploads/mgm/downloads/92352100.pdf (retrieved on June 8, 2016)

Mikre, F. (2011). "The roles of information communication technologies in education: Review article with emphasis to the computer and internet". Ethiopian Journal of Education and Sciences, 6(2), 109126.

Kebudayaan, K. P. (2016). Salinan Peraturan Menteri Pendidikan Dan Kebudayaan Nomor 22 Tahun 2016 Tentang Standar Proses Pendidikan Dasar Dan Menengah.

Setiyawan, wayan. 2014. An Analys of English Teachers' Literacy in Using ICT at SMA Dwijendra Denpasar in Academic Year 2013/2014: Ganesha University of Education. 